\title{
Osteoporosis, falls, and age in fracture of the proximal femur
}

\author{
C COOPER, D J P BARKER, JULIE MORRIS, R S J BRIGGS
}

\begin{abstract}
The relative importance of osteoporosis and risk of falling in causing hip fracture is not known. Femoral neck bone mass was measured in 708 elderly people, all of whom had fallen and injured a hip. Below 75 years of age there was a steep increase in relative risk of fracture with reduced bone mass, measured by Singh grade. Above that age the increase in risk was small, and neuromuscular responses which protect the skeleton against trauma may be more important than bone mass.
\end{abstract}

\section{Introduction}

The incidence of fracture of the proximal femur in the elderly depends on bone strength, the risk of falling, and the effectiveness of neuromuscular responses that protect the skeleton against trauma. ${ }^{1}$ The relative importance of these three influences is, however, unknown, and the strategy to prevent hip fractures is therefore a matter of conjecture.

The steep rise in incidence with age, coupled with the results of histological and radiological studies, has led to the conclusion that the principal determinant of hip fractures is age related bone loss. ${ }^{2}$ On this basis the strategy for prevention should be directed at retarding this loss. Postmenopausal hormone replacement treatment has been widely advocated for this purpose. ${ }^{3}$ Recent studies, however, have failed to show consistent differences in the bone mass, measured at a number of skeletal sites, in patients with fractures and in controls from the general population. ${ }^{46}$ This has led to the hypothesis that the primary cause of hip fracture in the elderly is an increased likelihood of falling rather than reduced bone mass. ${ }^{4}$ Hence, it is argued, public health measures should be directed at prevention of falls by removing environmental hazards or by improving neuromuscular protective responses to trauma.

We measured femoral neck bone mass in an unselected series of

MRC Environmental Epidemiology Unit, Southampton General Hospital, Southampton SO9 4XY

C COOPER, MA, MRCP, epidemiologist

D J P BARKER, PHD, FRCP, director

JULIE MORRIS, MSC, statistician

R S J BRIGGS, MSC, MRCP, senior lecturet in geriatric medicine

Correspondence to: Dr Cooper. elderly people who presented to hospital casualty departments after having fallen and sustained a hip injury. We compared the bone mass of those who had fractured their hip and of those who had not.

\section{Patients and methods}

We reviewed the records and radiographs of patients aged 50 years and over who had fallen and sustained a hip injury and presented to casualty departments in Southampton and Salisbury health districts from April 1984 to March 1985. Patients who had sustained hip injuries from causes other than falls, such as road traffic accidents, were excluded. In each case the injury was sufficiently severe to require pelvic radiography to exclude a fracture. Patients were identified from the casualty registers. Completeness of ascertainment of those with fractures was checked from ward lists and hospital discharge records. Patients not living within the two health districts were excluded. From the pelvic radiographs a single trained observer (CC) graded the femoral neck trabecular pattern of each subject according to the Singh scale. ${ }^{7}$ This six point scale ranges from grade 6 , where all major trabeculae are visible, to grade 1 , where only the primary compressive trabeculae are seen. We have previously shown that these gradings correlate with the ash weight to volume ratio of the femoral head and are sufficiently repeatable for use in epidemiological studies. ${ }^{8}$ The femur on the contralateral side to the injury was examined; the identity of the patient was unknown to the observer, who was presented with a view of a single intact proximal femur.

After the study was complete within observer variation of the gradings was assessed by re-examination of 100 of the radiographs, 50 each from patients with fractures and from those without. The second examination was carried out in such a way that the observer was unaware of his earlier report on the radiographs; these were presented to him in random order.

\section{Results}

Seven hundred and eight subjects fulfilled the entry criteria to the study, of whom 456 ( 109 men and 347 women) had sustained a hip fracture and 252 ( 72 men and 180 women) had not. Table I shows that those without fractures tended to be in the younger age groups. Within each age group there were more women than men.

Among both groups of patients the proportion with lower Singh grades increased with age (table II). Within each age group, however, the distribution of grades differed between the two groups of patients. Grades tended to be higher in those without fractures. When expressed as relative risk of fracture according to grade this difference gave an increase in risk from grades 5 and 6 up to grades 1 and 2 (figure). This gradient was significant $(p<0.01)$ in each age group. The increase was steeper at younger 
ages, the relative risks for grades 1 and 2 being 33.0 at ages 50-64 years compared with 17.7 at $65-74,5.4$ at $75-84$, and 5.4 at 85 and over. To examine the risks in each sex we amalgamated the age groups (table III). The steeper increase in risk at younger ages was found in both sexes. Although it

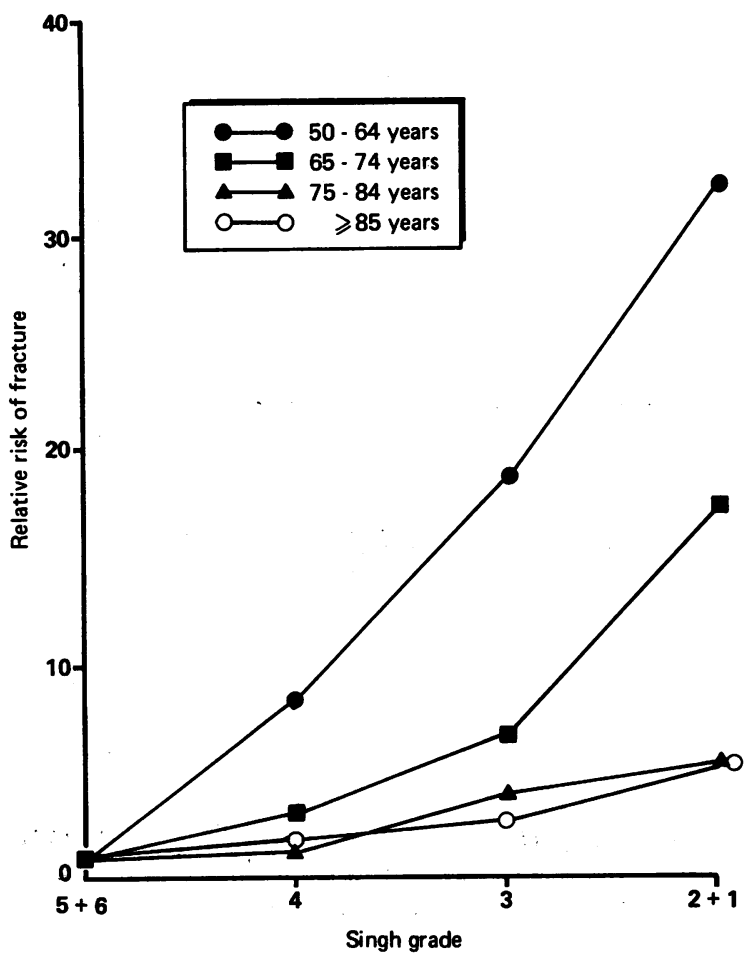

Relative risk of hip fracture in each Singh grade and age group.

TABLE I-Number of patients by age and sex according to the presence or absence of hip fracture

\begin{tabular}{lccccc}
\hline & \multicolumn{2}{c}{ With fracture } & & \multicolumn{2}{c}{ Without fracture } \\
\cline { 2 - 3 } \cline { 5 - 6 } Age (years) & Men & Women & & Men & Women \\
\hline $50-64$ & 19 & 33 & & 28 & 54 \\
$65-74$ & 37 & 56 & & 16 & 45 \\
$75-84$ & 42 & 138 & & 25 & 44 \\
$\geqslant 85$ & 11 & 120 & & 3 & 37 \\
\hline \multicolumn{1}{c}{ Total } & 109 & 347 & & 72 & 180 \\
\hline
\end{tabular}

TABLE II-Distribution of Singh grades and relative risks for hip fracture by age

\begin{tabular}{|c|c|c|c|c|c|c|}
\hline \multirow[b]{2}{*}{$\begin{array}{c}\text { Age } \\
\text { (years) }\end{array}$} & \multirow[b]{2}{*}{$\begin{array}{l}\text { Singh } \\
\text { grade }\end{array}$} & \multicolumn{2}{|c|}{ No of patients } & \multirow[b]{2}{*}{$\begin{array}{c}\text { Relative } \\
\text { risk }\end{array}$} & \multirow{2}{*}{$\begin{array}{c}95 \% \\
\text { Confidence } \\
\text { interval }\end{array}$} & \multirow{2}{*}{$\begin{array}{c}\chi^{2} \text { test for } \\
\text { linear trend, } \\
\mathbf{d f}=1 \\
(p \text { value })\end{array}$} \\
\hline & & $\begin{array}{l}\text { With } \\
\text { fracture }\end{array}$ & $\begin{array}{l}\text { Without } \\
\text { fracture }\end{array}$ & & & \\
\hline $50-64$ & $\begin{array}{c}5+6 \\
4 \\
3 \\
1+2\end{array}$ & $\begin{array}{r}14 \\
23 \\
8 \\
7\end{array}$ & $\begin{array}{r}66 \\
13 \\
2 \\
1\end{array}$ & $\begin{array}{c}1 \\
8 \cdot 3 \\
18 \cdot 9 \\
33 \cdot 0\end{array}$ & $\begin{array}{l}3.6 \text { to } 19 \\
5 \cdot 0 \text { to } 71 \\
7 \cdot 1 \text { to } 155\end{array}$ & $33.8(<0.01)$ \\
\hline $65-74$ & $\begin{array}{c}5+6 \\
4 \\
3 \\
1+2\end{array}$ & $\begin{array}{l}23 \\
30 \\
29 \\
11\end{array}$ & $\begin{array}{r}37 \\
16 \\
7 \\
1\end{array}$ & $\begin{array}{c}1 \\
3 \cdot 0 \\
6 \cdot 7 \\
17 \cdot 7\end{array}$ & $\begin{array}{l}1.4 \text { to } 6.6 \\
2.6 \text { to } 17 \\
3.3 \text { to } 94\end{array}$ & $21.8(<0.01)$ \\
\hline $75-84$ & $\begin{array}{c}5+6 \\
4 \\
3 \\
1+2\end{array}$ & $\begin{array}{l}35 \\
49 \\
52 \\
44\end{array}$ & $\begin{array}{r}26 \\
27 \\
10 \\
6\end{array}$ & $\begin{array}{l}1 \\
1 \cdot 3 \\
3 \cdot 9 \\
5 \cdot 4\end{array}$ & $\begin{array}{l}0.7 \text { to } 2 \cdot 7 \\
1 \cdot 7 \text { to } 8 \cdot 8 \\
2 \cdot 1 \text { to } 14\end{array}$ & $17 \cdot 5(<0.01)$ \\
\hline$\geqslant 85$ & $\begin{array}{c}5+6 \\
4 \\
3 \\
1+2\end{array}$ & $\begin{array}{r}8 \\
39 \\
41 \\
43\end{array}$ & $\begin{array}{r}6 \\
17 \\
11 \\
6\end{array}$ & $\begin{array}{l}1 \\
1 \cdot 7 \\
2 \cdot 8 \\
5 \cdot 4\end{array}$ & $\begin{array}{l}0.5 \text { to } 5.7 \\
0.8 \text { to } 9.5 \\
1.5 \text { to } 19\end{array}$ & $7 \cdot 4(<0.01)$ \\
\hline All ages & $\begin{array}{c}5+6 \\
4 \\
3 \\
1+2\end{array}$ & $\begin{array}{l}80 \\
141 \\
130 \\
105\end{array}$ & $\begin{array}{r}135 \\
73 \\
30 \\
14\end{array}$ & $\begin{array}{c}1 \\
3 \cdot 3 \\
7 \cdot 3 \\
12 \cdot 7\end{array}$ & $\begin{array}{l}2 \cdot 2 \text { to } 4 \cdot 8 \\
4 \cdot 6 \text { to } 12 \\
7 \cdot 3 \text { to } 22\end{array}$ & $108 \cdot 7(<0.01)$ \\
\hline
\end{tabular}

TABLE III-Distribution of Singh grades and relative risks for hip fracture by age and sex

\begin{tabular}{|c|c|c|c|c|c|c|}
\hline \multirow[b]{2}{*}{$\begin{array}{c}\text { Age } \\
\text { (years) }\end{array}$} & \multirow[b]{2}{*}{$\begin{array}{l}\text { Singh } \\
\text { grade }\end{array}$} & \multicolumn{2}{|c|}{ No of patients } & \multirow[b]{2}{*}{$\begin{array}{l}\text { Relative } \\
\text { risk }\end{array}$} & \multirow{2}{*}{$\begin{array}{c}95 \% \\
\text { Confidence } \\
\text { interval }\end{array}$} & \multirow{2}{*}{$\begin{array}{c}\chi^{2} \text { test for } \\
\text { linear trend, } \\
\mathrm{df}=1 \\
(\mathrm{p} \text { value })\end{array}$} \\
\hline & & $\begin{array}{l}\text { With } \\
\text { fracture }\end{array}$ & $\begin{array}{l}\text { Without } \\
\text { fracture }\end{array}$ & & & \\
\hline \multicolumn{7}{|c|}{ Men } \\
\hline$<75$ & $\begin{array}{c}5+6 \\
4 \\
3 \\
1+2\end{array}$ & $\begin{array}{r}22 \\
19 \\
10 \\
5\end{array}$ & $\begin{array}{r}34 \\
8 \\
1 \\
1\end{array}$ & $\begin{array}{c}1 \\
3 \cdot 7 \\
15 \cdot 5 \\
7 \cdot 7\end{array}$ & $\begin{array}{l}1.4 \text { to } 9.6 \\
2.8 \text { to } 86 \\
1.1 \text { to } 54\end{array}$ & $12 \cdot 8(<0.01)$ \\
\hline$\geqslant 75$ & $\begin{array}{c}5+6 \\
4 \\
3 \\
1+2\end{array}$ & $\begin{array}{l}15 \\
10 \\
17 \\
11\end{array}$ & $\begin{array}{r}10 \\
13 \\
4 \\
1\end{array}$ & $\begin{array}{l}1 \\
0 \cdot 5 \\
2 \cdot 8 \\
7 \cdot 3\end{array}$ & $\begin{array}{l}0.2 \text { to } 1.6 \\
0.8 \text { to } 11 \\
1.0 \text { to } 53\end{array}$ & $5.3(<0.01)$ \\
\hline All ages & $\begin{array}{c}5+6 \\
4 \\
3 \\
1+2\end{array}$ & $\begin{array}{l}37 \\
29 \\
27 \\
16\end{array}$ & $\begin{array}{r}44 \\
21 \\
5 \\
2\end{array}$ & $\begin{array}{l}1 \\
1 \cdot 6 \\
6 \cdot 4 \\
9 \cdot 5\end{array}$ & $\begin{array}{l}0.8 \text { to } 3.3 \\
2.4 \text { to } 17 \\
2.5 \text { to } 36\end{array}$ & $19.4(<0.01)$ \\
\hline \multicolumn{7}{|c|}{ Women } \\
\hline$<75$ & $\begin{array}{c}5+6 \\
4 \\
3 \\
1+2\end{array}$ & $\begin{array}{l}15 \\
34 \\
27 \\
13\end{array}$ & $\begin{array}{r}69 \\
21 \\
8 \\
1\end{array}$ & $\begin{array}{c}1 \\
7 \cdot 4 \\
15 \cdot 5 \\
59 \cdot 8\end{array}$ & $\begin{array}{c}3.5 \text { to } 16 \\
6.5 \text { to } 37 \\
14.8 \text { to } 241\end{array}$ & $52.0(<0.01)$ \\
\hline$\geqslant 75$ & $\begin{array}{c}5+6 \\
4 \\
3 \\
1+2\end{array}$ & $\begin{array}{l}28 \\
78 \\
76 \\
76\end{array}$ & $\begin{array}{l}22 \\
31 \\
17 \\
11\end{array}$ & $\begin{array}{l}1 \\
2 \cdot 0 \\
3 \cdot 5 \\
5 \cdot 4\end{array}$ & $\begin{array}{l}1.0 \text { to } 3.9 \\
1.7 \text { to } 7 \cdot 4 \\
2.4 \text { to } 12 \cdot 1\end{array}$ & $18.4(<0.01)$ \\
\hline All ages & $\begin{array}{c}5+6 \\
4 \\
3 \\
1+2\end{array}$ & $\begin{array}{r}43 \\
112 \\
103 \\
89\end{array}$ & $\begin{array}{l}91 \\
52 \\
25 \\
12\end{array}$ & $\begin{array}{c}1 \\
4 \cdot 6 \\
8 \cdot 7 \\
15 \cdot 7\end{array}$ & $\begin{array}{l}2 \cdot 8 \text { to } 7 \cdot 3 \\
5 \cdot 1 \text { to } 15 \\
8 \cdot 4 \text { to } 30\end{array}$ & $88.0(<0.01)$ \\
\hline
\end{tabular}

TABLE IV-Singh grades of 100 femoral necks on repeat examination by one observer

\begin{tabular}{ccccc}
\hline $\begin{array}{c}\text { Grade at } \\
\text { second } \\
\text { examination }\end{array}$ & $1+2$ & 3 & \multicolumn{4}{c}{ Grade at first examination } \\
\cline { 2 - 5 } & 27 & 1 & 0 & $5+6$ \\
\hline $1+2$ & 2 & 18 & 8 & 0 \\
3 & 1 & 3 & 11 & 0 \\
4 & 0 & 0 & 4 & 1 \\
$5+6$ & & & & 24 \\
\hline
\end{tabular}

was more pronounced in younger women than younger men, the difference was not significant.

Two hundred and twenty one of the fractures were intracapsular and 235 extracapsular. The distribution of Singh grades and the relation between age, sex, and increase in risk were similar for the two fractures. In the assessment of within observer variation (table IV) 80 of the 100 radiographs were identically graded at the two separate examinations. In 19 there was disagreement by one grade below or above and in one by two grades.

A check of hospital records showed that $92 \%$ of all patients admitted to the two hospitals with hip fractures during the study period had been included in the study.

\section{Discussion}

Among people aged 50 years and over who presented to hospital casualty departments having fallen and injured their hips femoral neck bone mass, measured by the Singh grade, was less among those who sustained a fracture at this site than among those who did not. This was seen consistently in each age group and in both men and women. The relative risks of fracture associated with reduced bone mass were large, especially among younger women.

Most previous studies of bone mass in patients with hip fractures have measured sites other than the hip, including the metacarpals, distal radius, and lumbar spine. ${ }^{9}$ As age related bone loss does not occur at the same rate throughout the skeleton inferences about bone mass in the femoral neck based on measurements at other sites are uncertain. ${ }^{10}$ The Singh index provides a swift, inexpensive method of assessing femoral neck bone mass. The results correlate with the ash weight to volume ratio of excised femoral heads, and, although fallible in the classification of individuals, the method 
provides an epidemiological tool to estimate bone mass in groups of subjects. $^{8}$ All our observations were made by a single trained observer, and a formal test of repeatability showed no evidence of systematic variations that could have led to the difference observed.

Three case-control studies using controls from the general population, rather than people who had fallen, showed an increase in risk of fracture with reduced Singh grade. ${ }^{11-13}$ In contrast, two similar studies using dual photon absorptiometry showed only small differences in the bone mineral content of cases and controls. ${ }^{514}$ One interpretation of these findings is that the Singh index reflects some aspect of bone morphology that is more closely related to bone strength than is the bone mineral content as measured by photon absorptiometry.

The study population comprised an unselected series of elderly patients with hip injuries resident in two adjacent health districts. The cases included $92 \%$ of all patients in the districts who underwent inpatient treatment for hip fracture during the one year study period. The controls were subject to selection by those factors that determine attendance at the casualty department by elderly people who fall and injure their hips. We think it unlikely that these factors are closely related to bone mass and hence it is unlikely that selection bias produced the large differences in the bone mass of cases and controls.

Three interacting factors may contribute to the risk of hip fracture: bone strength, the risk of falling, and the effectiveness of the neuromuscular responses that protect the skeleton against trauma. Our study was designed to examine two of these factors while allowing for the third. We conclude that at ages below around 75 years reduced bone mass, or osteoporosis, is a strong independent risk factor for fracture. Above that age it may be less important than neuromuscular protective responses.
We thank the consultants and staff of the accident and emergency, radiology, and orthopaedic departments of the Southampton and Salisbury hospitals, who gave us access to their records. We also thank Mrs Shirley Simmonds, who helped to retrieve the radiographs, and Mrs Bridget Wilde, who typed the manuscript.

\section{References}

1 Melton LJ, Riggs BL. Risk factors for injury after a fall. Clinics in Geriatric Medicine 1985;1:525-

2 Nordin BEC. Clinical significance and pathogenesis of osteoporosis. Br Med $\mathcal{F}$ 1971;i:571-6.

3 Stevenson JC, Whitehead MI. Postmenopausal osteoporosis. Br Med f 1982;285:585-8.

4 Aitken JM. Relevance of osteoporosis in women with fracture of the femoral neck. $\mathrm{Br}$ Med $\mathcal{F}$ 1984;288:597-601.

5 Bohr $\mathrm{H}$, Schaadt $\mathrm{O}$. Bone mineral content of femoral bone and the lumbar spine measured in women with fracture of the femoral neck by dual photon absorptiometry. Clin Orhop 1983;179:240-5.

6 Evans RA, Ashwell JR, Dunstan CR. Lack of metabolic bone disease in patients with fracture of the femoral neck. Aust NZ J Med 1981;11:158-61.

7 Singh M, Nagrath AR, Maini PS. Changes in trabecular pattern of the upper end of the femur as an index of osteoporosis. $\mathcal{F}$ Bone Joint Surg [Am] 1970;52:457-67.

8 Cooper C, Barker DJP, Hall AJ. Evaluation of the Singh index and femoral calcar width as epidemiological methods for measuring bone mass in the femoral neck. Clin Radiol 1986;37: 123-5.

9 Cummings SR. Are patients with hip fractures more osteoporotic? Review of the evidence. Am $\mathcal{f}$ Med 1985;78:487-94.

10 Mazess RB. On ageing bone loss. Clin Orthop 1982;165:239-52.

11 Pogrund H, Rigal WM, Makin M, Robin G, Menczel J, Steinberg R. Determination of osteoporosis in patients with fractured femoral neck using the Singh index. Clin Orthop osteoporosis in pate.
1981;156:189-95.

12 Horsman A, Nordin BEC, Simpson M, Speed R. Cortical and trabecular bone status in elderly women with femoral neck fracture. Clin Orihep 1982;166:143-51.

13 Lips P, Taconis WK, Van Ginkel FC, Netelenbos JC. Radiologic morphometry in patients with femoral neck fractures and elderly control subjects. Comparison with histomorphometric parameters. Clin Orhop 1984;183:64-70.

14 Riggs BL, Wahner HW, Seeman E, et al. Changes in bone mineral density of the proximal femur and spine with aging: differences between the post-menopausal and senile osteoporosis syndromes. f Clin Invest 1982;70:716-23.

(Accepted 24 April 1987)

\title{
Measles in children who have malignant disease
}

\author{
J KERNAHAN， J McQUILLIN，A W CRAFT
}

\begin{abstract}
A review study examined the clinical course of measles diagnosed in children being treated for malignant disease in Newcastle upon Tyne during 1973-86. Of the 17 cases diagnosed, five were fatal. Factors associated with a favourable outcome were a typical rash and Koplik's spots, which were accompanied by a detectable serum antibody response and the disappearance of measles giant cells from nasopharyngeal secretions. Pneumonitis severe enough to require assisted ventilation was invariably fatal. Pneumonitis and encephalitis were the main complications. Treatment included immunoglobulin, interferon, and ribavirin, but none could clearly be shown to be effective.

The comparatively low mortality in this series may have been due to the extensive use of the fluorescent antibody technique in Newcastle during the study period and therefore detection of less severe cases as compared with other reports.
\end{abstract}

Department of Child Health, Royal Victoria Infirmary, Newcastle upon Tyne NE1 4LP

J KERNAHAN, MB, FRCP, consultant paediatrician

A W CRAFT, MD, FRCP, consultant paediatrician

Department of Virology, Royal Victoria Infirmary, Newcastle upon Tyne NE1 4LP

J MCQUILLIN, BSC, FIMLS, top grade scientific officer

Correspondence to: Dr Craft.

\section{Introduction}

Despite the availability of a safe measles vaccine for years and the significant reduction in measles in the United States as a result of a statutory immunisation policy ${ }^{1}$ fewer than $60 \%$ of children in Britain are currently immunised against the disease. ${ }^{2}$ This may reflect a lack of concern among some of the health care professions and a misguided tendency in Britain to regard measles as a comparatively mild childhood disease with few sequelae, scarcely worth preventing. Consequently the incidence of measles in Britain is high enough to expose children who are at special risk to a potentially lethal infection.

Serious measles infections have long been recognised as a lifethreatening complication of childhood cancer. ${ }^{34}$ In this group of children the occurrence of severe measles without rash (or with an atypical rash) and presenting as giant cell pneumonia or encephalopathy with a high mortality has been well documented..$^{3.7}$ In view of atypical clinical signs which may occur in immunosuppressed children and the lack of a comprehensive viral diagnostic service in some hospitals a proportion of unexplained deaths in the past may have been due to unrecognised measles. ${ }^{8}$

In order to clarify the serious consequences of measles infection in children having treatment for cancer Gray et al have reported the experience of four large paediatric oncology units; they found that only three of 22 children survived the infection and that one of these was left severely handicapped. ${ }^{9}$ None of the units had the benefit of a rapid viral diagnostic service during the period of study, and so probably only the most obvious and serious cases were recorded. 